\title{
Особености на лечението на алергичен ринит и полипозен риносинуит с продукта Ринитал
}

\author{
S. B. Bezshapochnyi, N. B. Sonnik, \\ V. V. Loburets
}
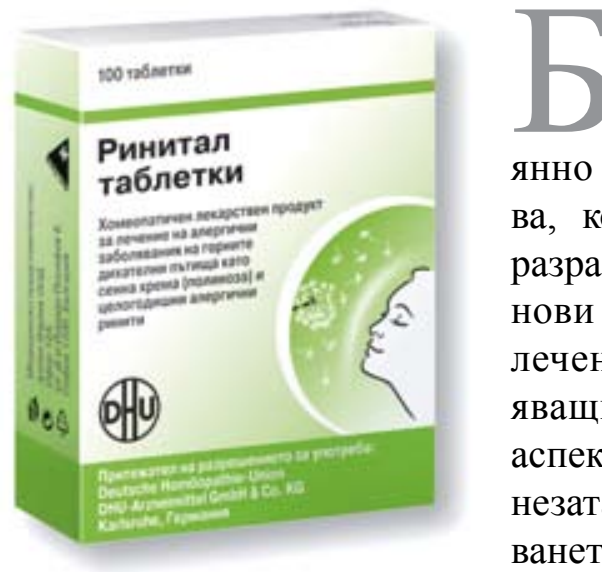

роят на боледуващите от АР постоянно се увеличава, което изисква разработването на нови методи на лечение, повлияващи различни аспекти от патогенезата на заболяването.

Ето защо въвеждането на лекарства, комбиниращи подобрена ефикасност с минимални нежелани ефекти, е належаща практическа цел. Въвеждането на комплексните хомеопатични лекарства с антиалергична активност в клиничната практика способства за разрешаването на този проблем.

Едно от лекарствата, отговарящо на всички тези изисквания, е комбинираният растителен хомеопатичен препарат Rhinital (DHU, Germany), съдържащ три монотерапевтични вещества: Galphimia glauca D3 - въздейства върху лигавицата на носа и параназалните синуси, нормализира отделянето на назален секрет и упражнява антиалергичен ефект; Luffa operculata D4 - намалява свръхсекрецията и отока на назалната лигавица; Cardiospermum halicacabum D3 - отслабва придружаващия алергичните и възпалителни заболявания сърбеж.

Rhinital се произвежда в съответствие със стандартите на добрата производствена практика
(GMP) и е изпитан в мултицентрови проучвания, в съответствие със стандартите на добрата клинична практика (GCP).

Резюме: Целта на проучването е да направи динамична оценка на терапевтичния ефект на комбинирания продукт Rhinital при пациенти с интермитентен и персистиращ алергичен ринит (AP) спрямо ефекта на Loratadine, препоръчван от Международната работна група за лечение на ринита (International Rhinitis Management Working Group), както и да проучи възможността за прилагане на Rhinital при пациенти с хроничен полипозен риносинуит в предоперативния и постоперативен периоди.

Динамичната оценка на степента на интензивност на симптомите на АР е направена в 1-ва, 2-ра и 4-та седмици на лечението в тестовите и сравнителните групи. Интензивността на симптомите е оценена чрез 5-степенна скала. При оценяване на действието на продуктите е взет предвид не само лечебният им ефект, но и поносимостта и честотата на възникване на нежелани лекарствени реакции. Мукоцилиарният клирънс и ринопневмометричните индекси са определени в проучваните групи и при 20 здрави лица (контролна група); направена е оценка на състоянието на назалната лигавица.

В проучваните групи е установен положителен ефект от приложените лечения, без съществени разлики в динамиката на отслабване на симптомите на AP между тестовите групи Rhinital и сравнителните групи Loratadine. Rhinital е действал бързо и е бил по-ефективен при пациентите с 
ИАР. Положителният ефект на Rhinital е доказан и при пациентите с хроничен полипозен риносинуит (ХПР) в предоперативен и постоперативен периоди. Три месеца след лечението с Rhinital статусьт на дишането през носа е бил нормализиран при всички пациенти, като не са били наблюдавани признаци на АР и рецидиви на полипите.
Участници в проучването: 109 пациенти на възраст от 16 до 55 години с диагностициран интермитентен алергичен ринит (ИАР), персистиращ алергичен ринит (ПАР) и хроничен полипозен риносинуит (ХПР).

\begin{tabular}{|l|c|l|}
\hline \multicolumn{1}{|c|}{ Група } & Брой пациенти & \multicolumn{1}{c|}{ Диагноза и лечение } \\
\hline Контролна група & 20 & Здрави доброволци от 20 до 25 години \\
\hline Тестова група 1 & 18 & Пациенти с ИАР + Rhinital \\
\hline Тестова група 2 & 26 & Пациенти с ПАР + Rhinital \\
\hline Тестова група 3 & 15 & Пациенти с ПРС + Rhinital \\
\hline Сравнителна група 1 & 10 & Пациенти със ИАР + лоратадин \\
\hline Сравнителна група 2 & 10 & Пациенти с ПАР + лоратадин \\
\hline Сравнителна група 3 & 10 & Пациенти с ПРС + лоратадин \\
\hline
\end{tabular}

Методи на проучването: ендомикрориноскопия (EMRS), оценка на мукоцилиарния клирънс (MCC), ринопневмометрия (RPM) и статистически методи за оценяване на резултатите.

Поставянето на диагноза на пациентите е извършено въз основа на следните данни: анамнеза и ход на заболяването, клинични находки, резултати от ендоскопското, рентгенологичното, компютър-томографското и магнитно-резонансното изследвания.

\section{Rhinital е прилаган по следната схема:}

Пациенти с ИАР и ПАР: 1 таблетка 12 пъти дневно през първите 3 дни, 30 минути преди или след хранене, сублингвално, последвано от 1 таблетка 30 минути преди или след хранене, сублингвално в продължение на един месец.

\section{Пациенти с ХПР:}

в предоперативния период: 1 таблетка 12 пьти дневно през първите 3 дни, последвано от 1 таблетка в продължение на 9 дни;

в постоперативния период: 1 таблетка 3 пьти дневно в продължение на един месец.

Резултатите от лечението са оценявани въз основа на субективни и обективни критерии. Лечението с Rhinital е било ефективно при 97,1\% от пациентите с ИАР и при $88,7 \%$ от пациентите с ПАР (в сравнителната група този показател е бил около 88,4\%).

Следователно благоприятен лечебен ефект е бил наблюдаван при всички лечебни групи, но степента на регресия на симптомите е била поотчетливо изявена при пациентите, лекувани с Rhinital. Нещо повече, в края на първата седмица в тези групи е наблюдаван доста бързо постигнат лечебен ефект, най-вече при пациентите с ИАР.

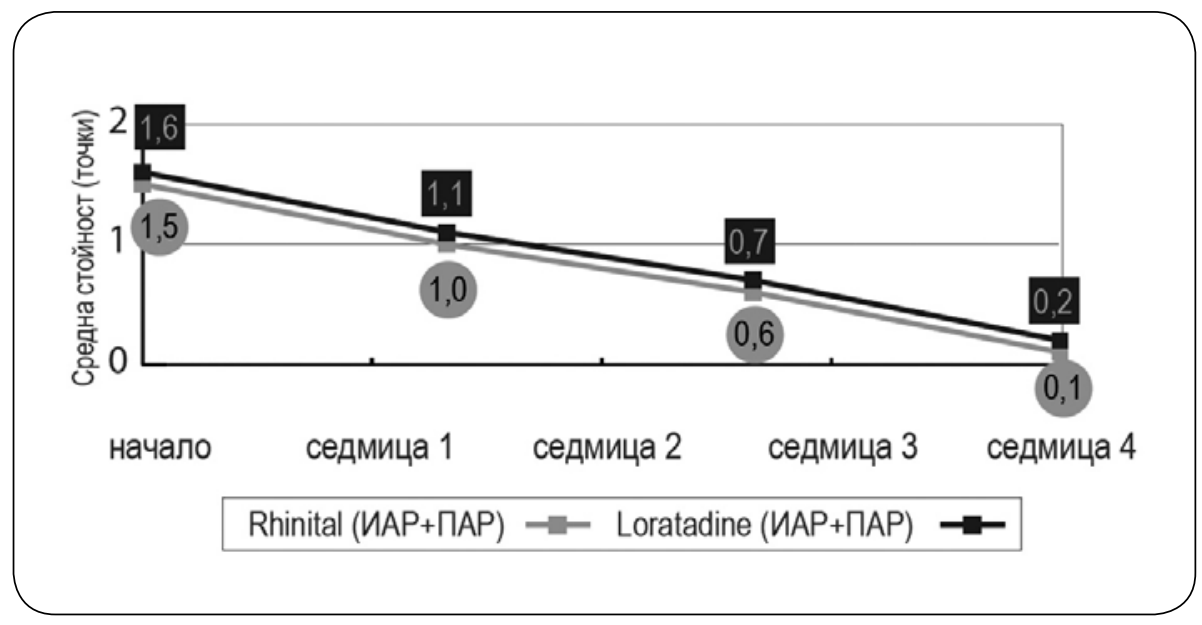

Фиг. 1. Промяна на субективните критерии за алергичен ринит (обща оценка) при тестовата група (Rhinital) спрямо сравнителната група (Loratadine) 
Обективните данни на пациентите с АР (фиг. 2 и фиг. 3) се основават на находките при ендоскопия на назалната кухина (оптична риноскопия), функционалното изследване на дишането през носа (ринопневмометрични находки) и отока на мукоцилиарната мукоза в назалната кухина, промяната в цвета на назалната мукоза и количеството отделен назален секрет.

- Тестова група (Rhinital) срещу сравнителна група (Loratadine)

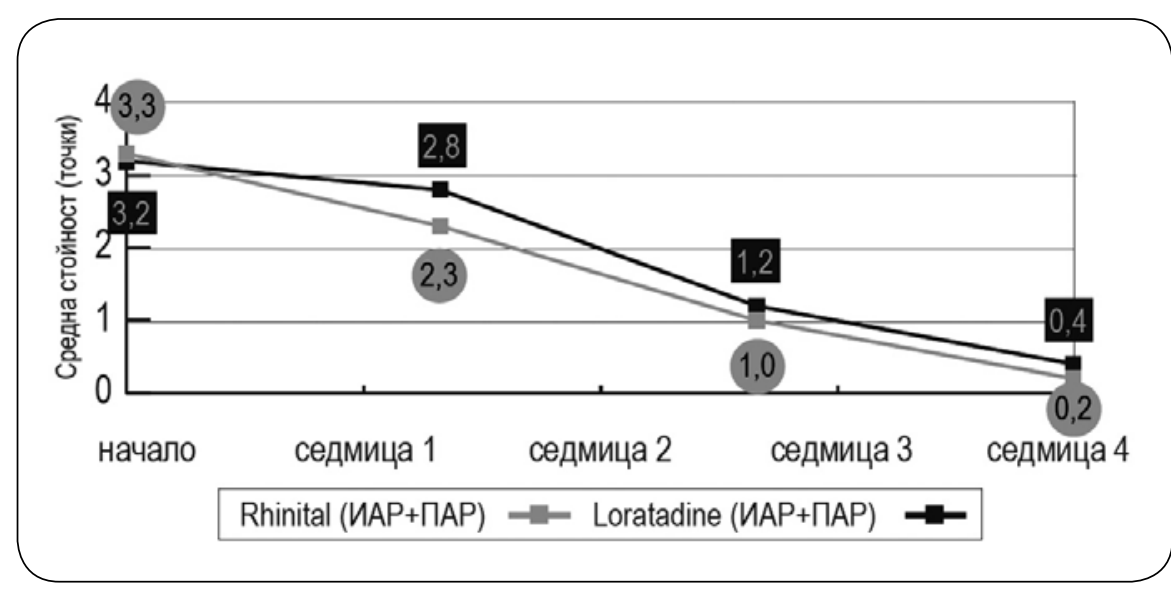

Фиг. 2. Промяна на обективния критерий за алергичен ринит „ринопневмометри“

- Тестова група (Rhinital) срещу сравнителна група (Loratadine)

Фиг. 3. Промяна на обективния критерий за алергичен ринит „мукоцилиарен клирънс“

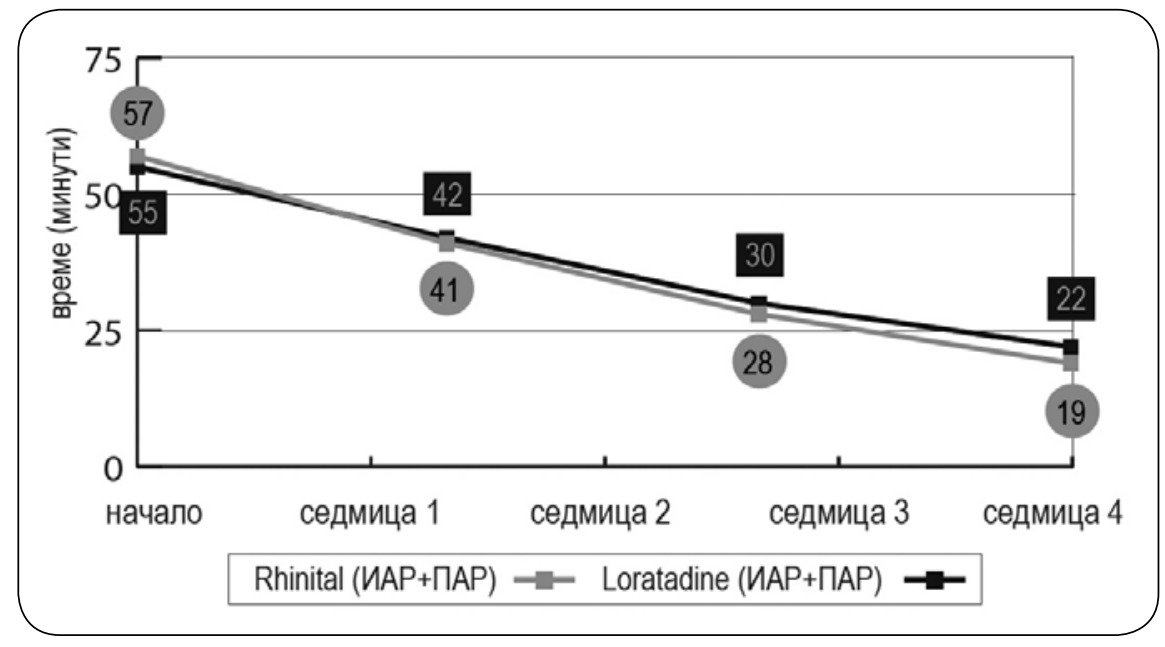

Подобрение на ринопневмометричните находки и мукоцилиарния клирънс е наблюдавано при всички лечебни групи. В края на лечението, обаче, при пациентите с ИАР, лекувани с Rhinital, скоростта на мукоцилиарен клирьнс не се е различавала статистически от съответстващите находки при здравите доброволци.

Rhinital е повлиял положително възстановяването на главните параметри на дишането през носа и състоянието на назалната мукоза при пациентите с АР.

Rhinital е допринесъл също за подобряване състоянието на пациентите с хроничен полипозен риносинуит (ХПР).
7 пациенти са били подложени на назална полипотомия, а 8 пациенти - на ендоназална ендоскопска полисинусотомия. Прилагането на Rhinital в постоперативния период е довело до нормализиране на находките при риноскопия, ринопневмометрия и мукоцилиарния клирънс.

При пациентите с ХПР, подложени на хирургично лечение, ефикасността на Rhinital в края на лечението е била $100 \%$ (в края на седмица 1 и 2 , тези показатели са били съответно $64,1 \%$ и $86,8 \%$ ). В сравнителната група показателят за ефикасност е бил средно 84,9\% (54,2\% и 69,6\%, съответно в края на седмица 1 и 2). 
В последяващия период пациентите са били изследвани 3 месеца след завършване на лечението. Дишането през носа се е нормализирало. Не са наблюдавани признаци на алергичен ринит или рецидив на полипите.
Не е съобщен нито един случай на нежелана лекарствена реакция по време на лечението с Rhinital, а неговата поносимост е била оценена като много добра при 100\% от пациентите.

\section{Заключителна оценка}

1. Ходът на главните симптоми на АР при пациентите с ПАР, лекувани с Rhinital, не се различава значимо от хода на симптомите при пациентите с ПАР, лекувани с антихистамин от рода на лоратадин, като Rhinital предоставя по-добър терапевтичен ефект при пациентите с ИАР.

2. Прилагането на Rhinital при пациенти c хроничен полипозен риносинуит в предоперативния и постоперативния периоди значимо ускорява подобрението на дишането през носа и обонянието.

3. Лечението c Rhinital е ефективно и абсолютно безопасно.

4. Rhinital ce препорьчва като предпочитано лекарство при лечение на интермитентен и персистиращ АР. 